\section{Earthquake phenomena}

The Earthquake Handbook. By Peter Verney. Pp. 224. (Paddington: New York and London, 1979). £5.50.

The Earthquake Handbook is an excellent description of earthquake phenomena and fulfills the objectives set out by the author in the introduction: "This is not a technical book: those wanting detailed scientific information [on earthquakes] should consult some of the many excellent works available ... My interest has been to explain this extraordinary natural phenomenon, referring to the records of past earthquakes, and in the light of modern progress in seismology, to help those who may live in or visit one of the many earthquake-prone areas of the world". The extensive quotations from eye-witnesses to the earthquakes described and the opinions of their contemporaries are certainly the outstanding features in this book, but the author's own contributions are clear and concise. The book is illustrated by an excellent selection of photographs, prints and drawings, all well reproduced. The text, figures, and quotations taken together give as good a description of what an earthquake is really like as any other source short of the earthquake experience itself. However, it should be understood that the treatment is descriptive and the technical aspects of seismology are scarcely touched on. In this sense the title of the book may have been poorly chosen.

The book begins with descriptions of the 1906 San Francisco and 1755 Lisbon earthquakes. These descriptions are amplified in subsequent sections of the book, together with a description of the 1923 Tokyo earthquake based principally upon the eye-witness account of H.W. Kinney, an author and editor who was travelling near Tokyo at the time. Shorter descriptions of the earthquakes at Port Royal, Jamaica (1692), London (1750), Calabria (1783), Messina (1908), Agadir (1960), Skopje (1963) and Alaska (1964) are also included.

The book then gives a very brief account of the various earthquake theories from the earliest mythologies (which generally attributed earthquakes to movement of the animal that was thought to support the Earth) to Aristotle (winds blowing through subterranean passages), Lucretius (rocks displaced in subterranean caverns), Ben Franklin (an electric discharge from a cloud to Earth), and John Michell in 1760 ("earthquakes were waves set up by the shifting masses of rock miles below the surface". Professor Koto of Japan in 1891 was apparently the first to assert that faulting was the cause (and not the effect) of the earthquake. Verney, of course, quotes extensively from those who attribute earthquakes to divine punishment (for example, Royal Society, 1752, "earthquakes only occur when people need chastening"). The section concludes with an elementary description of plate tectonics.

A description of earthquake geography and earthquake effects follows. The latter section is particularly concerned with tsunami (tidal waves generated by earthquakes) but includes discussions of earthquake noises and lights as well as the physiological shock experienced by earthquake survivors and even the motion sickness reported by some.

The basic rules for survival in an earthquake are given in a brief but

\section{Nutrition and national development}

Food and Nutrition Policy in a Changing World. By J. Mayer and J. Dwyer. Pp.300. (Oxford University Press: Oxford and New York, 1979.) $£ 8.25$.

LIKE many books which are edited rather than authored this slim volume seems to me to lack the sense of coherence and direction that would seem a sine qua non for it to achieve its aim of dissussing the need for placing food and nutrition in the larger context of national development. This failing is doubly said, as it is not merely a book, but a condensation of a five-volume report commissioned from the editors by UNICEF in order to "set forth goals for UNICEF and allied agencies for the next decade",

What use the report will be to UNICEF, only time will tell; I found the book unsatisfactory to read. Partly this was no doubt due to the level at which it was pitched, for as the editors warn: "The specialist would regard the book as nontechnical and somewhat cursory"'. But it was more than that: it was a sense that it was not a book at all but a collection of disparate chapters loosely edited and fitting together into a scheme which seemed only to exist as the various subheadings in the table of contents.

This is not to say that some of the individual chapters were not quite enjoyable as discrete essays: the editors themselves contributed a chapter entitled "Beyond Economics and Nutrition: The Complex Basis of Food Policy" which was a reprint of their polished critique of approaches to control of malnutrition, first published in Science. Some other chapters, notably those by Perisse and Ms Jeliffe, were also well written expositions of the views of the authors. But practical chapter that includes advice on how to prepare for a possible earthquake as well as how to behave during and after the shock. The final three chapters are brief, non-technical treatments of earthquake engineering, prediction, and control. I believe most scientists will find these final three chapters somewhat superficial.

The book is clearly intended for a lay audience, but I believe even seismologists will find the many quotations and general descriptions of real interest. However, the prospective reader is reminded of the author's admonition "This is not a technical book ....'. James C. Savage

James C. Savage is a geophysicist in the Office of Earthquake Research, US Geological Survey, Menlo Park, California.

in this I found the flaw with the book as a whole. Each author seemed to perform a solo item, without reference to his colleagues so that overall the book did not hang together.

I was irritated by such contraditions as Kimm and Donoso repudiating the idea of dietary protein deficiency on page 160 , while Winikoff invoked it en passant on page 184; or again that Winikoff's chapter advocating megadoses of vitamin $\mathrm{A}$ as an effective treatment for vitamin A deficiency was followed by an editorial note pointing out it was a high risk and probably ineffective strategy. Besides such tactical differences, there seemed also to be a difference in grand strategy between the advocates of economic intervention and those who felt that health care was specifically needed.

In general, I would not criticise any scientific work for the divergencies in views it contains. After all, without contradictions there is no science; the great mistakes in nutrition have arisen from professional certainty, not doubt. But the differences in view in this book are not productive ones. There is no air of creative tension between them; on the contrary, the overwhelming impression is that the authors have not even discussed their views with each other. I do not know why this has arisen, I suspect because of a lack of firm editorial control at the centre, and perhaps for some authors a lack of balanced scholarship in the area which they seek to discuss, but it is difficult to judge the extent of scholarship in the space allotted to each author. The editors would have done better to throw out some topics completely (for example, Dr Araujo's ludicrously terse "Nutrition Primer") and enlarge other issues in depth. But they did not, and I suspect the result is a book that will not interest the layman or satisfy the specialist.

John Rivers

John Rivers is Lecturer in Human Nutrition at the London School of Hygiene and Tropical Medicine, London, UK. 